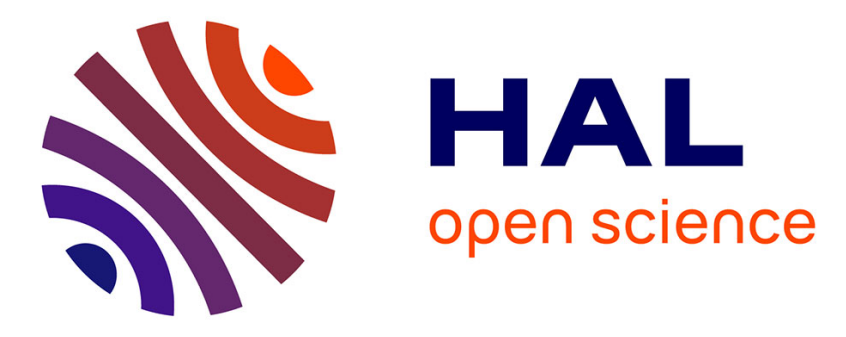

\title{
Can Interactive Art Installations Attract 15 Years Old Students to Coding?
}

\author{
Michail N. Giannakos, Finn Inderhaug Holme, Letizia Jaccheri, Irene \\ Dominguez Marquez, Sofia Papavlasopoulou, Ilse Gerda Visser
}

\section{To cite this version:}

Michail N. Giannakos, Finn Inderhaug Holme, Letizia Jaccheri, Irene Dominguez Marquez, Sofia Papavlasopoulou, et al.. Can Interactive Art Installations Attract 15 Years Old Students to Coding?. 14th International Conference on Entertainment Computing (ICEC), Sep 2015, Trondheim, Norway. pp.529-532, 10.1007/978-3-319-24589-8_51 . hal-01758440

\section{HAL Id: hal-01758440 \\ https://inria.hal.science/hal-01758440}

Submitted on 4 Apr 2018

HAL is a multi-disciplinary open access archive for the deposit and dissemination of scientific research documents, whether they are published or not. The documents may come from teaching and research institutions in France or abroad, or from public or private research centers.
L'archive ouverte pluridisciplinaire HAL, est destinée au dépôt et à la diffusion de documents scientifiques de niveau recherche, publiés ou non, émanant des établissements d'enseignement et de recherche français ou étrangers, des laboratoires publics ou privés.

\section{(c)(1)}

Distributed under a Creative Commons Attribution| 4.0 International License 


\title{
Can Interactive art installations attract 15 years old stu- dents to Coding?
}

\author{
Michail N. Giannakos, Finn Inderhaug Holme, Letizia Jaccheri, Irene Dominguez \\ Marquez, Sofia Papavlasopoulou, Ilse Gerda Visser \\ Norwegian University of Science and Technology (NTNU), Trondheim, Norway \\ \{michailg, letizia\}didi.ntnu.no; ffinninde, \\ ilsegv astud.ntnu.no contactenamtarucreations.com \\ sofia.papavlasopoulou@gmail.com
}

\begin{abstract}
In this art demonstration we will present the art installations which are at the center of a creative development program for young students with the name KODELØYPA. KODELØYPA is based on the philosophy of creative reuse of recycled materials and the open-source software Scratch and Arduino. KODELØYPA is based on an empirically validated framework, designed and implemented by researchers and artists.
\end{abstract}

Keywords: Creative activities; software and hardware development; physicaldigital creativity, art and technology

\section{INTRODUCTION}

The Norwegian University of Science and Technology (NTNU) offers six science frameworks for Norwegian primary and secondary schools with the objective of raising interest in various science disciplines from physics, chemistry, mathematics, biology, energy, to coding. The framework, dedicated to raise interest in coding is based on the hypothesis that the interactions between the children and the artifacts in a creative activity are vital [5]. In this framework children learn coding by playfully interacting with digital artifacts that also exhibit physical and aesthetical characteristics. Such artifacts allow children to learn by iteratively testing and rebuilding their designs [2]. The interactive installations presented by this paper are the concrete results of our efforts to develop an authentic environment for creative learning that helps school children, to build their own digital game based on the interplay of digital and physical objects. KODELØYPA represents a good example of novel directions in the creative learning. In particular, in this paper we focus on the artifacts specifically designed and created for the workshop program where children collaboratively engaged in modifying interactive artworks that react to events in the physical world [6]. 


\section{KODELOYPA: AN APPROACH TO ENHANCE CREATIVE LEARNING}

KODELØYPA is based on open source software and hardware and consisted of tutorials on open source tools, artifacts, creative sessions and students' demonstrations/presentations. Up to date, KODELØYPA has organized four workshops, allowing 63 students to be introduced to coding (about 15 children per workshop). Our thesis is that coding skills improve children understanding of the design and functionalities that underlie all aspects of interfaces, technologies, and systems we encounter daily. It is important that everyone should use code in some ways for expressive purposes to better communicate, interact with others, and build relationships.
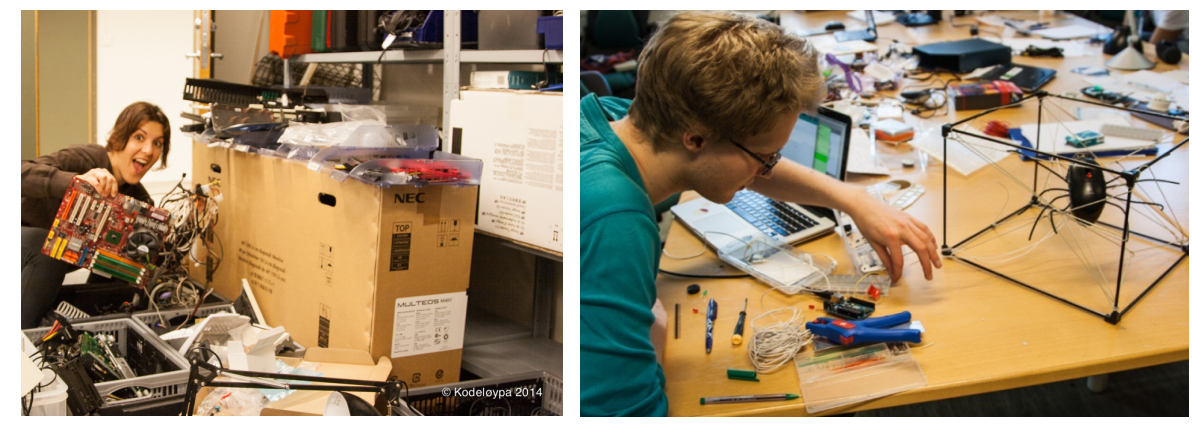

Fig. 1. Left: The artist organizes old computer pieces and other garbage to prepare the components to be used for the physical phase. Right: One of the assistant animates the spider installation by help of motors.

KODELØYPA is based on a well-documented and validated framework [4, 5]. It enables children to engage in programming languages (i.e., Scratch) and programmable hardware platforms (i.e., Arduino), to enable them to become the creators and programmers of their own playful experiences. KODEL $\varnothing$ YPA takes place at NTNU's premises. Children attending the workshops are instructed and assisted by one artist, and 6 assistants; who have organized the process in advance (Fig. 1). The art demonstration will present the artifacts developed during KODEL $\varnothing$ YPA (Fig. 2 shows one art installation).

\section{REQUIREMENTS FOR THE EXHIBITIONS}

In the demonstration we will illustrate the process (Fig. 3), as well as the tangible results from the KODELØYPA program. These are interactive installations made by a team of artists, designers, and programmers for the purpose of enabling young stu- 
dents to become creators of interactive experience with both artistic and technical qualities.

We can exhibit up to five interactive installations. They vary in size but they are all smaller than 1 cubic meter. Each one can be connected to a PC and is programmable. A screen with a video about the program will be provided.

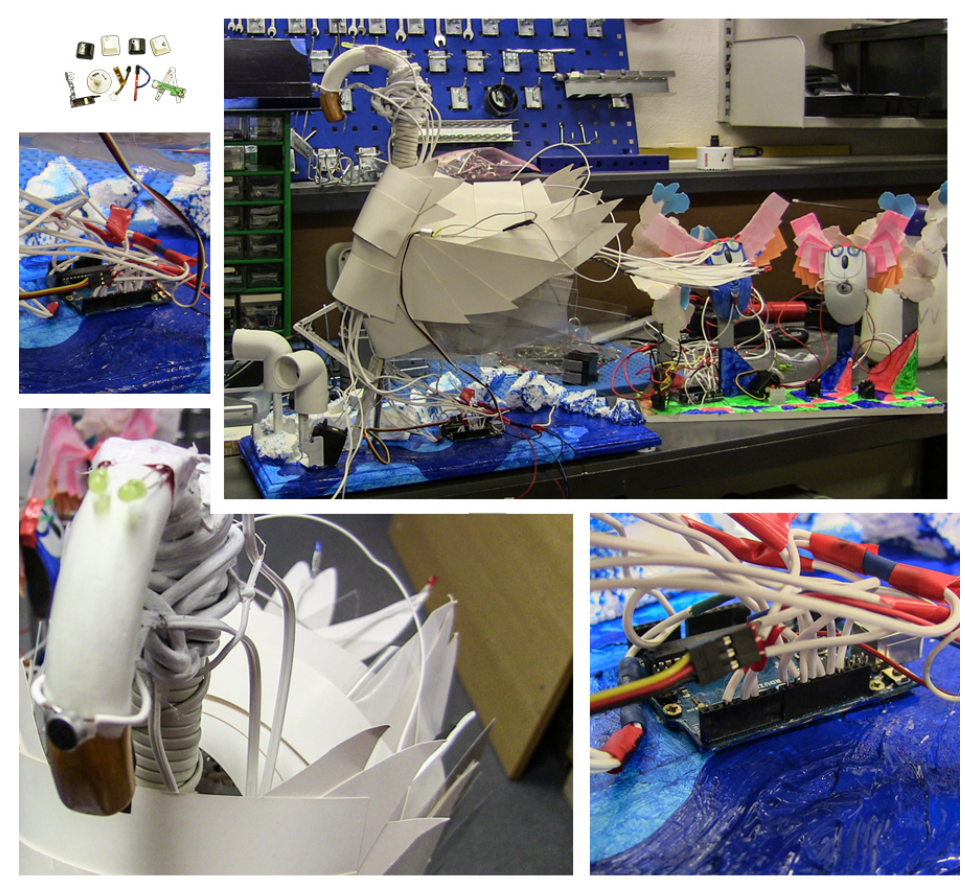

Fig. 2. One concrete installation: the swan. 


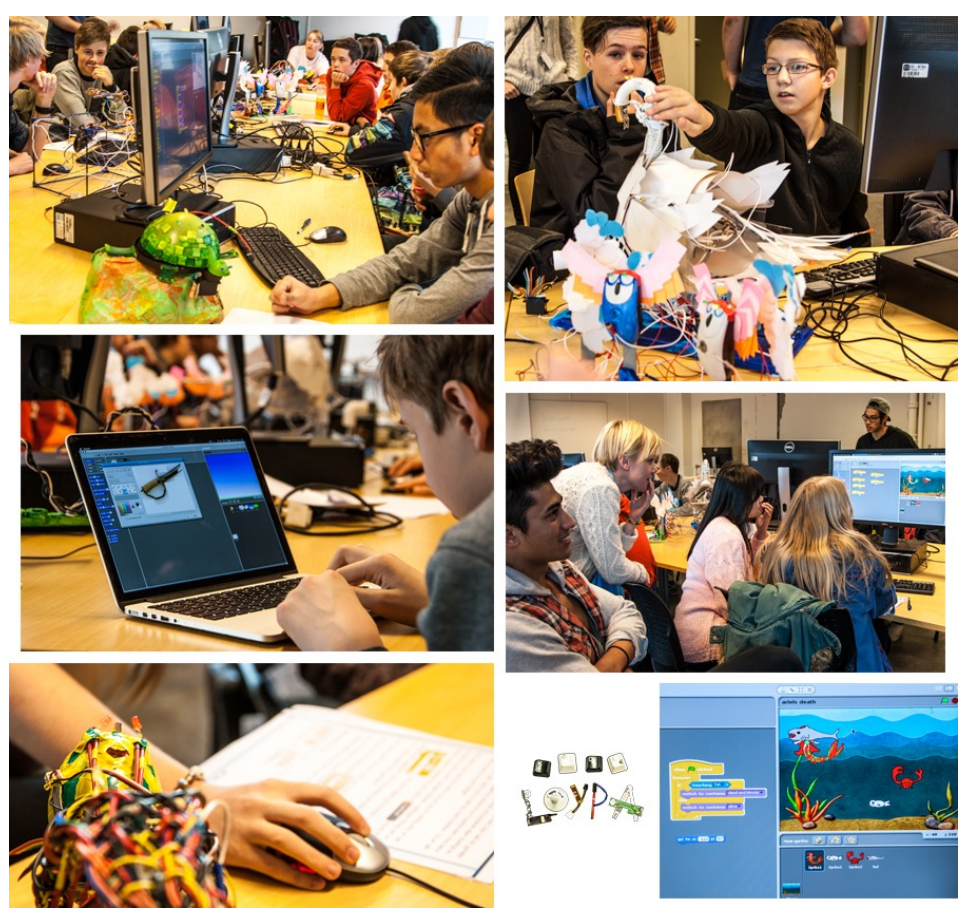

Fig. 3. Picture from one workshop: children play, program, interact with the assistants.

\section{References}

1. Buechley, L., Eisenberg, M., Catchen, J. and Crockett, A.: The LilyPad Arduino: Using Computational Textiles to Investigate Engagement, Aesthetics, and Diversity in Computer Science Education. In Proc. CHI '08, pp. 423-432, ACM Press, (2008)

2. Cassell, J.: Towards a Model of Technology and Literacy Development: Story Listening Systems, Journal of Applied Developmental Psychology vol. 25(1), pp. 75-105 (2004)

3. Edwards, C., Gandini, L. and Forman, G.: The hundred languages of children: the Reggio Emilia approach to early childhood education (2nd ed) (NJ, Ablex Publishing) (1998)

4. Giannakos, M. N. and Jaccheri, L. What motivates children to become creators of digital enriched artifacts? In Proceedings of the 9th ACM Conference on Creativity \& Cognition, pp. 104-113, ACM Press (2013)

5. Jaccheri, L., and Giannakos, M. N.: Open source software for entertainment. In Entertainment Computing-ICEC 2012, Springer LNCS, vol. 7522, pp. 604-607 (2012)

6. Papert, S.: Mindstorms: Children, Computers, and Powerful Ideas. Basic Books New York, NY (1980)

7. Price, S. and Rogers, Y.: Let's get physical: the learning benefits of interacting in digitallyaugmented physical spaces. Computers \& Education vol. 43(1-2), pp. 137-151 (2004) 